[1] Штіфзон О., Новіков П., Баган Т. Розробка адаптуючого fuzzy-logic пристрою для керування в умовах параметричної нестаціонарності. Східно-європейський журнал передових технологій. Харків, 2018. Том 1 № 2. C. 30-37. https://doi.org/10.15587/1729-4061.2018.121749.

[2] Michael Mulholland. Applied Process Control: Essential Methods 1st Edition. 2016. p. 460.

[3] Åström KJ, Hägglund T. Advanced PID Control. ISA - The Instrumentation, Systems and Automation Society. 2006. $460 \mathrm{p}$.

[4] Коновалов М.А., Бунке А.С. Основы новой стратегии синтеза систем оптимального управления. Киев, 2014. $280 \mathrm{c}$.

[5] Kovrigo Yu., Konovalov M., Bunke A. Modernizing the heat load control system of a oncethrough boiler unit at a thermal power station using a dynamic corrector. Thermal Engineering. 2012. № 59(10). Pp. 772-778. https://doi.org/10.1134/S0040601512100072.

\title{
References:
}

[1] V. Arkhangelsky et al., Fuzzy-control systems. Kiev, 208 p., 1997.

[2] A. Beloglazov and Yu. Kosenko, "Study of stability of fuzzy management systems," in Izvestiya SFEDU. Engineering Sciences, no. 2(139), pp. 127-132, 2013.

[3] D. Manchuk and S. Chernyi, "Stability analysis of fuzzy control systems in a small, large, as a whole," in. Modern High Technologies, no. 5 (1), pp. 74-75, 2014. URL: http://top-technologies.ru/ru/article/view?id=33710 (Accessed: 29.05.2020)

[4] A. Ladanyuk et al., "The problem of ensuring the stability of intelligent control system of technological objects," in Scientific Works of NUFT, vol. 25, iss. 2, pp. 7-15, 2019.doi: https://doi.org/10.24263/2225-2924-2019-25-2-3.

[5] P. Novikov, "Control processes automation of thermal power plant unit inertial channels using a two-channel fuzzy controller," Ph.D. dissertation, National Technical University of Ukraine "Igor Sikorsky Kyiv Polytechnic Institute", Kyiv, Ukraine, 2019.

[6] O. Shtifzon et al, "Development of the adaptive fuzzy-logic device for control system in conditions of parametric nonstationary plant," in Eastern-European Journal of Enterprise Technologies, 1/2 (91), pp. 30-37, 2018. doi: https://doi.org/10.15587/1729-4061.2018.121749.

[7] M. Mulholland. Applied Process Control: Essential Methods, 1st ed., 2016, 460 p.

[8] K.J. Astrom and T. Hagglund "Advanced PID Control," in The Instrumentation, Systems and Automation Society, p. 460, 2006.

[9] M. Konovalov and A. Bunke, Fundamentals of a new strategy for the synthesis of optimal control systems. Kyiv, 2014, $280 \mathrm{p}$.

[10] Yu. Kovrigo et al., "Modernizing the heat load control system of a oncethrough boiler unit at a thermal power station using a dynamic corrector," Thermal Engineering, vol. 59, pp. 772-778, Sep. 2012. doi: https://doi.org/ 10.1134/S0040601512100072.

\section{PASSIVE IDENTIFICATION OF MULTIVARIABLE STABILIZATION SYSTEM ELEMENTS' DYNAMICS}

\author{
Osadchy S. I. ${ }^{1}$, Zozulia V. A. ${ }^{2}$ \\ ${ }^{1,2}$ Central Ukrainian National Technical University, Kropyvnytskyi, Ukraine \\ ORCID: ${ }^{1}$ https://orcid.org/0000-0002-1811-3594, ${ }^{2}$ https://orcid.org/0000-0003-3793-4686 \\ E-mail: ${ }^{1}$ srg2005@ukr.net, ${ }^{2}$ irish38@ukr.net
}

Copyright (C) 2018 by author and the journal "Automation of technological and business - processes. This work is licensed under the Creative Commons Attribution International License (CC BY). http://creativecommons.org/licanses/by/4.0

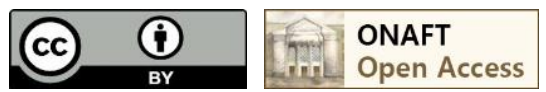

DOI: https://doi.org/10.15673/atbp.v12i1.1701 
http://www.atbp.onaft.edu.ua/

Abstract. Topicality. Increasing domestic automatic control systems competitiveness requires the design work intensification based on the implementation of modern information technologies. Such implementation necessary condition is based on the control object dynamic model's improvement and real operating perturbations characteristics estimates' development with the help of the latest identification methods design and usage.

Objective. To create an algorithm for structural identifying the controller transfer functions matrix, the control object's system of ordinary differential equations and the perturbations spectral densities matrix. The algorithm initial data include stabilization system control signals and it's output signals obtained in standard operating conditions.

Method. Minimization of an identification errors weighted dispersions sum by the Wiener-Kolmogorov's method.

Results. Equations that allow one to calculate matrices of the controller's transfer functions and of the perturbation's spectral densities, as well as to find a control object's ordinary differential equations system that minimize the identification error's variance have been found. Processing results of the stabilization system's work simulation based on these equations proves their correctness and illustrates the methodology of applying the new identification algorithm.

Conclusions. Application of the new identification algorithm is limited by the following conditions fulfillment: signals in the stabilization circuit belong to a set of centered stationary random processes; measurement noises operate at the controller input and are independent from perturbations, the sensors transfer matrix is known.

Анотація. Актуальність. Підвищення конкурентоспроможності вітчизняних систем автоматичного керування вимагає інтенсифікаиії проектно-конструкторський робіт на основі впровадження сучасних інформаційних технологій. Однією з необхідних умов зазначеного впровадження є уточнення моделей динаміки об'єктів керування та збурень, які виникають в реальних умовах функціонування, на основі розробки та впровадження новітніх методів ідентифікації.

Мета. Створити алгоритм структурної ідентифікації матриці передаточних функиій регулятору, системи звичайних диференціальних рівнянь об’єкта керування та матриці спектральних щільностей збурень, вихідними даними якого є записи зміни сигналів керування та сигналів на системи стабілізації, отримані у штатних умовах функиіонування.

Метод. Мінімізація суми зважених дисперсій похибок ідентифікації методом Вінера - Колмогорова.

Результати. Знайдені рівняння, щуо дозволяють розрахувати матриці передаточних функцій регулятора та спектральних шільностей збурення, а також знайти систему звичайних диференціальних рівнянь об'єкта керування, які мінімізують дисперсію похибки ідентифікації. Обробка результатів імітаційного моделювання роботи системи стабілізації на основі даних рівнянь доводить їх коректність та ілюструє методику застосування нового алгоритму ідентифікаціiі.

Висновки. Застосування нового алгоритму ідентифікаџї обмежене виконанням наступних умов: сигнали в контурі стабілізації належать до множини центрованих стаціонарних випадкових процесів; шуми вимірювання діють на вході регулятору та не залежать від збурень, матриия передаточних функиій датчиків відома.

Key words: system, control, identification, stabilization, spectral densities matrix

Ключові слова: система, управління, ідентифікація, стабілізація, матриця спектральної щільності

\section{Introduction}

Efforts to increase designers work productivity and quality in the field of the objects or processes control complexes designing have necessitated the introduction of new technologies for the competitive computer integrated systems design. One such technology, cited in the monographs [1,2], has proven itself well in the creation of a complex for modeling spacecraft motion in the Earth atmosphere. Its application made it possible to design and implement from the first presentation an optimal controller for the motion control of a three-ton of mass and six degrees of freedom object without performing preliminary design and debugging steps .

\section{Literature overview and problem statement}

A necessary condition for this technology use is the presence of control object's and perturbations dynamics models acting on it under real operating conditions. As it is proved in [1], the source of such models is a corresponding identification task solution. There is a large majority of identification algorithms [1,3] but almost all of them allow one to find the control objects and disturbances dynamics' models in the absence of correlation between the control signals' and disturbances vectors' components. At the same time, a wide range of control objects in real operating conditions work as a part of a close loop control system, the feedback of which is impossible to break.

While the feedback is switched on then cross correlation between control and disturbance signals vectors is obtained. If this condition is evident then the identification method set's range is significantly limited. For example, the monograph [4] and article [5] present algorithms for identifying the dynamics characteristics of a control plant operating as a part of a follow-up system. At the same time, there is a lack of identification algorithms for the control objects dynamics estimation, when such objects are an integral part of the stabilization system. 
http://www.atbp.onaft.edu.ua/

\section{Research purpose and task}

The purpose of this article is to develop a convenient algorithm for structural identification of the multidimensional control plant's dynamics, whether it is stable or not, and disturbances acting on it during operation as a part of the stabilization system, by measuring the control signals vector and the system output signals vector.

To achieve this goal, the following task was posed in terms of the work [1] and solved. Suppose that there is a multidimensional stabilization system (Fig. 1), which includes a control plant, measurement information sensors and a regulator. The m-dimensional vector of control signals $\mathrm{u}_{0}$ and the n-dimensional unit intensity white noises vector $\Delta$ act on the inputs of the control object.

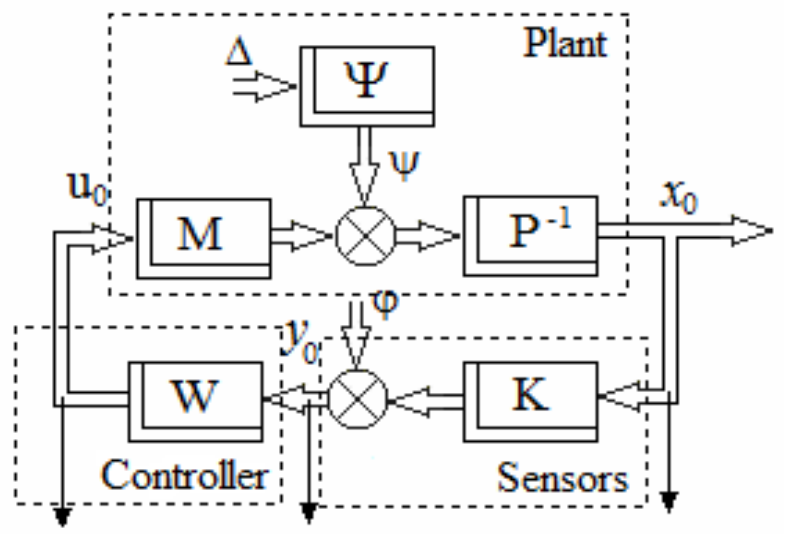

Fig. 1 - stabilization system block diagram

An $n$-dimensional vector of output signals $x_{0}$ acts at the output of the Plant (fig. 1). All components of the vector $x_{0}$ are measured using Sensors with a given matrix of transfer functions $K$ and on this basis an $n$-dimensional vector of Controller input signals $y_{0}$ is formed

$$
y_{0}=K x_{0}+\varphi
$$

where $\varphi$ is $n$-dimensional measurement noises vector, which represents $n$-dimensional random stationary centered process with known spectral densities matrix $S_{\varphi \varphi}$. Since the disturbances' $\Delta$ and measurement noises' $\varphi$ appearance sources have different physical nature, too often, then the hypothesis of their independence is accepted in the work.

Suppose that the control object's dynamics is characterized by a linearized system of ordinary differential equations

$$
P x_{0}=M u_{0}+\psi \text {, }
$$

where $P, M$ are polynomial matrixes from the differentiation operator; $\psi$ is $\mathrm{n}$ - dimensional vector of perturbations that are formed with a help of the multidimensional filter. The filter's transfer functions matrix is denoted $\Psi$ (fig. 1). In this case, the identification problem is formulated as follows: using the known vectors $\mathrm{u} 0$, $\mathrm{x} 0$ and $\mathrm{y} 0$, as well as given sensors' transfer functions matrix $\mathrm{K}$ and spectral noise densities matrix $\mathrm{S} \varphi \varphi$, find the order and parameters of the matrices $\mathrm{P}, \mathrm{M}, \Psi$ and $\mathrm{W}$ that minimize the following identification quality indicator

$$
J=\frac{1}{j} \int_{-j \infty}^{j \infty} \operatorname{tr}\left(S_{\varepsilon \varepsilon}^{\prime} R\right) d s,
$$

where $j$ is imaginary unit; $\operatorname{tr}$ is a trace of matrix; $S_{\varepsilon \varepsilon}^{\prime}$ is the transposed matrix of identification errors $\varepsilon$ which is equal

$$
\varepsilon=x_{0}-\Phi z
$$

$\Phi$ is the identified close loop system transfer functions matrix; $z$ is the expanded vector of the system input signals

$$
z=\left[\begin{array}{l}
\varphi \\
\Delta
\end{array}\right] ;
$$

$R$ is the weighting positively-definite symmetric matrix; $s$ is the Fourier argument $(s=\mathrm{j} \omega)$. Taking into account the structural scheme (Fig. 1), as well as equations (1) - (3), allows us to represent the relationship between the blocks of the matrix $\Phi$ and the matrices $\mathrm{P}, \mathrm{M}, \Psi, \mathrm{W}$ as the following set of expressions

$$
\begin{gathered}
\Phi=\left[\begin{array}{cc}
\Phi_{11} & \Phi_{12}
\end{array}\right]=F_{0}^{-1}\left[\begin{array}{ll}
M W & \Psi
\end{array}\right] ; \\
F_{0}=P-M W .
\end{gathered}
$$

So, the research task is to minimize the functional (2). 
http://www.atbp.onaft.edu.ua/

\section{Research methods and materials}

To solve the problem on the basis of the Wiener-Khinchin theorem in a vector form [7] applied to the vector (3), we find the equation for the connection of the matrix $S_{\varepsilon \varepsilon}^{\prime}$ with the block matrix $\Phi$

$$
S_{\varepsilon \varepsilon}^{\prime}=S_{x 0 x 0}^{\prime}-S_{z x 0}^{\prime} \Phi_{*}-\Phi S_{x 0 z}^{\prime}+\Phi S_{z z}^{\prime} \Phi_{*}
$$

in which $S_{\mathrm{x} 0 \mathrm{x} 0}^{\prime}$ is the random process's $x_{0}$ spectral densities transposed matrix, found as a result of processing the experimental data; an index "*" - denotes the Hermitian conjugation [6] of the matrix; $S_{\mathrm{zx} 0}^{\prime}$ is a transposed matrix of cross spectral densities between vector random processes $\mathrm{z}$ and $\mathrm{x} 0$, which, in accordance with Figs. 1 and the Wiener-Hinchin theorem is equal

$$
S_{z x 0}^{\prime}=\left[S_{y 0 x 0}^{\prime}-S_{x 0 x 0}^{\prime} K_{*} \quad S_{\Delta x 0}^{\prime}\right] \text {, }
$$

where $S_{\Delta \mathrm{x} 0}^{\prime}$ is the fractional rational matrix which has no singularities in the complex plane right half, found as the result of the Wiener factorization to the left [8] of the following sum

$$
S_{\Delta x 0}^{\prime} S_{x 0 \Delta}^{\prime}=S_{x 0 x 0}^{\prime}-\left(S_{y 0 x 0}^{\prime}-S_{x 0 x 0}^{\prime} K_{*}\right)\left(S_{\varphi \varphi}^{\prime}\right)^{-1}\left(S_{x 0 y 0}^{\prime}-K S_{x 0 x 0}^{\prime}\right)
$$

$S_{\text {zz }}^{\prime}$ is the vector's (4) spectral densities transposed matrix, which, taking into account the accepted assumptions about disturbances and noise, as well as on the basis of the above mentioned theorem, is defined as

$$
S_{z z}^{\prime}=\left[\begin{array}{cc}
S_{\varphi \varphi}^{\prime} & O_{n} \\
O_{n} & E_{n}
\end{array}\right]
$$

$O_{\mathrm{n}}$ is a matrix with zero elements of the $n \times n$ size; $E_{\mathrm{n}}$ is the unit matrix of the $n \times n$ size also.

Substitution of the obtained results (7), (8) into the functional (2) made it possible to present this identification quality indicator in the form

$$
J=\frac{1}{j} \int_{-j \infty}^{j \infty} \operatorname{tr}\left(R S_{x 0 x 0}^{\prime}-R S_{z x 0}^{\prime} \Phi_{*}-R \Phi S_{x 0 z}^{\prime}+R \Phi S_{z z}^{\prime} \Phi_{*}\right) d s .
$$

Minimization of the functional (10) on the class of stable and physically realized variable matrices $\Phi$ by the WienerKolmogorov method is reduced to finding the matrix $\Phi[1,2]$, which ensures equality of the functional (10) first variation to zero. This variation is defined by the equation

$$
\delta J=\frac{1}{j} \int_{-j \infty}^{j \infty} \operatorname{tr}\left[\delta \Phi_{*}\left(-R S_{z x 0}^{\prime} .+R \Phi S_{z z}^{\prime}\right)+\left(-S_{x 0 z}^{\prime} R+S_{z z}^{\prime} \Phi_{*} R\right) \delta \Phi\right] d s,
$$

where $\delta \mathrm{J}, \delta \Phi$ are corresponding functions variations. The identically equal to zero condition for the variation (11) under the assumption that only stable variations of functions $\delta \mathrm{J}, \delta \Phi$ may be appeared looks like following

where the matrix $\Gamma$ is a result of Weiner factorizing [6] the matrix $R$

$$
\Phi=\Gamma^{-1}\left(T_{0}+T_{+}\right) D^{-1}
$$

$$
R=\Gamma_{*} \Gamma ;
$$

$T_{0}+T_{+}$is the fractional rational matrix with poles in the left half-plane of the complex variable, which is the result of the product separation (splitting) [3] shown below

$$
T_{0}+T_{+}+T_{-}=S_{z x 0}^{\prime} D_{*}^{-1}
$$

$D$ is the result of factorizing [8] the transposed spectral densities matrix $S_{\mathrm{zz}}^{\prime}$

$$
D D_{*}=S_{z z}^{\prime} \text {. }
$$

Led out thus equation (12) makes it possible on the base of the measured signals vectors find out the unique matrix $\Phi$ that is linked with unknown matrices $\mathrm{P}, \mathrm{M}, \mathrm{W}$ and $\Psi$ by the equations (5), (6).

Since the controller (Fig. 1) has one input and one output, on which the fully measurable vectors $\mathrm{y}_{0}$ and $\mathrm{u}_{0}$ are acting, identification of the controller transfer function matrix $\mathrm{W}$ can be carried out according to the following relation known from control systems statistical dynamics

$$
W=S_{u 0 y 0}^{\prime}\left(S_{y 0 y 0}^{\prime}\right)^{-1},
$$

where $S_{\mathrm{u} 0 \mathrm{y} 0}^{\prime}$ is the transposed cross spectral densities matrix of the vectors $u_{0}$ and $y_{0}$ obtained from experimental data; $S_{\mathrm{y} 0 \mathrm{y} 0}^{\prime}$ is the transposed spectral densities matrix of the vector $y_{0}$.

Further matrices M, $\Psi$ identification is based on the two tasks fulfillment: looking for the matrix (6) and solving the equation (5) relatively to $\mathrm{M}$ and $\Psi$. The search for matrix (6) could be made whit the help of two algorithms. The first one is based on the algorithm [9] for one-sided poles removal from a fractional rational matrices $\Phi_{11}$ and $\Phi_{12}$. The second algorithm is used simple multifractional factorization with the help of state space approach [11]. If the matrix $F_{0}$ is known the equation's (5) solution is defined as

$$
\begin{gathered}
M=F_{0} \Phi_{11} S_{y 0 y 0}^{\prime}\left(S_{y 0 u 0}^{\prime}\right)^{-1} ; \\
\Psi=F_{0} \Phi_{12} .
\end{gathered}
$$


http://www.atbp.onaft.edu.ua/

In turn, as follows from the equation (6), the polynomial matrix $\mathrm{P}$ is equal to

$$
P=F_{0}\left(E_{n}+\Phi_{11}\right) \text {. }
$$

So, the research task is completely fulfilled. Based on known structural identification frequency domain methods, a new identification algorithm has been obtained. It's usage allows one to find the multidimensional control plant's dynamics model, whether it is stable or not, and disturbances acting on it during operation as a part of the stabilization system, by measuring the control signals vector and the system output signals vector. The new algorithm's branch of use is limited by the case when the measurement noise's and perturbation's sources of the control plant are of different origin.

Demonstration of the new identification algorithm's advantages and research of it application features requires the use of the simulation method for modeling the stabilization system work.

4. The identification results of the plant dynamics as a part of the stabilization system

Suppose that the following initial data on the dynamics of system elements (Fig. 1) are given

$P=s^{2}+4 s+11.11 ; M=8.8889(s+5) ; K=1 ; \Psi=\frac{2 \sqrt{2.5}}{\sqrt{\pi}(s+2.5) 0.3^{2}} ; S_{\varphi \varphi}^{\prime}=\frac{0.09}{\pi\left(-s^{2}+10^{2}\right)} ; W=-1.8$.

It is necessary to find records of the signals $u_{0}, x_{0}, y_{0}$, to identify polynomials $P, M$ and transfer functions $W$, $\Psi$ with the help of the equations (12) - (19).

The first part of this task has been solved thru the system's (Fig. 1) model design that is built with the help of the tool Simulink. Structural transformations of the scheme (Fig. 2), (Fig. 3) have been carried out during model designing. Such transformations main purpose was to exclude the possibility of using circuit elements with unacceptable transfer functions. An incorrect or unacceptable transfer function in Matlab is considered such a rational fractional function whose numerator polynomial order exceeds the order of the denominator polynomial.

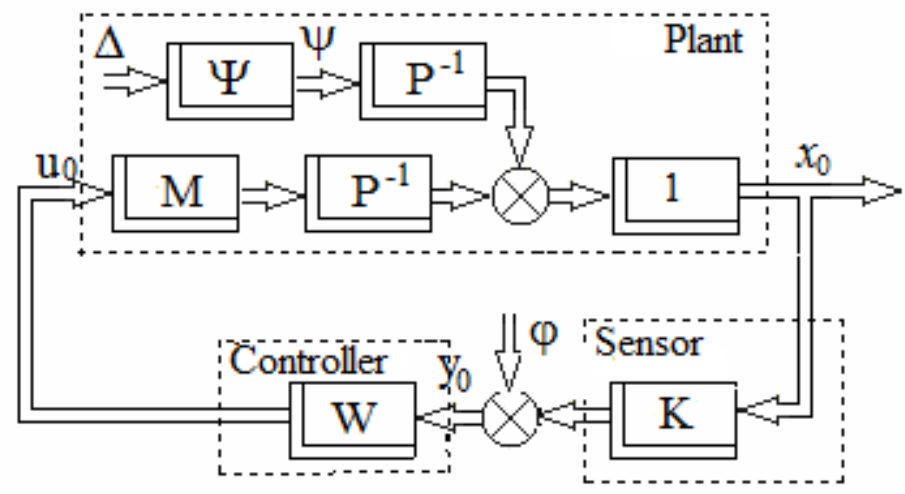

Fig. 2 - the fist step of transforming the stabilization system's block diagram

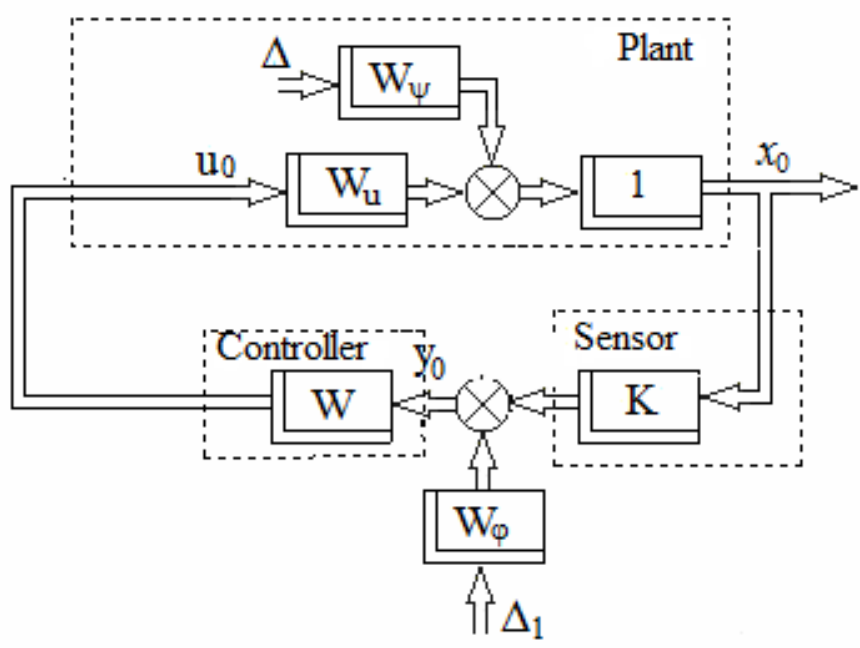

Fig. 3 - the second step of transforming the stabilization system's block diagram

As a result of the second transformation step one have been find transfer functions $W_{\mathrm{u}}$, $W_{\psi}$ that are equal to

$$
W_{u}=P^{-1} M=\frac{8.8889(s+5)}{s^{2}+4 s+11.11} ; W_{\psi}=P^{-1} \Psi=\frac{35.136}{(s+2.5)\left(s^{2}+4 s+11.11\right)} ;
$$


and the producing filter transfer function $W_{\varphi}$ (Fig. 3) that is served for producing the random process $\varphi$ from a white noise with unit intensity. The transfer function $W_{\varphi}$ is found as a following result of the spectral density $S_{\varphi \varphi}^{\prime}$ factorization [3]

$$
W_{\varphi}=\frac{0.3}{\sqrt{\pi}(s+10)} \text {. }
$$

The block diagram (Fig. 3) made it possible to design an imitation SIMULINK model (Fig.4) that was necessary for obtaining the random signals' $\mathrm{u} 0, \mathrm{x} 0$, y0 records. These records were made with a help of oscillograph blocks that were marked Scope, Scope1 and Scope2 in the diagram (Fig. 4).

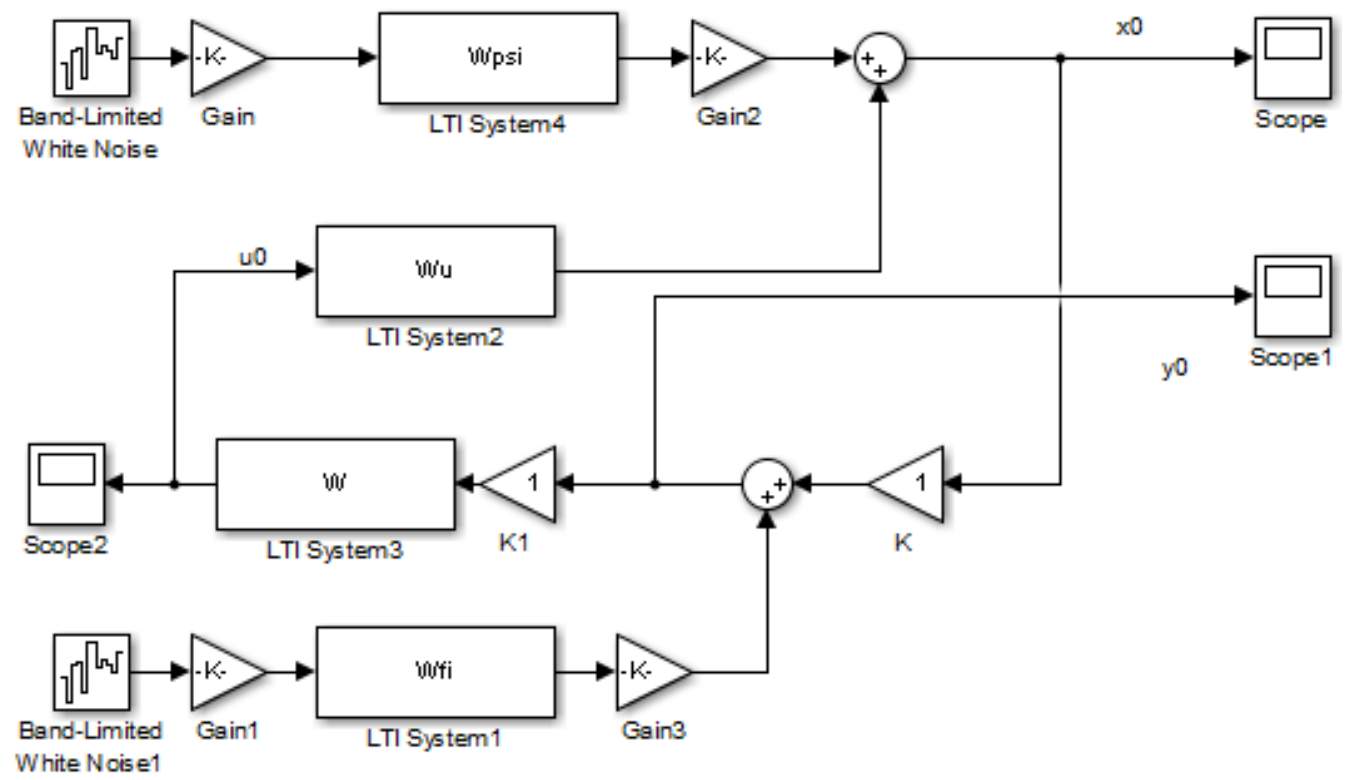

Fig. 4 - stabilization system's SIMULINK model

It was used blocks Band-Limited White Noise and Band-Limited White Noise1 as independent white noises' sources that were necessary for signals $\Delta$ and $\Delta_{1}$ generation. Amplifier blocks $-\mathrm{K}$ - are additional to the scheme in the Fig. 3 and are necessary to compensate the pump-loss effect of unit intensity pseudo random oscillations' additional power.

The simulation made it possible to obtain realizations of the signals $\mathrm{u}_{0}, \mathrm{x}_{0}, \mathrm{y}_{0}$, the first six seconds of which are presented in graphs in the Fig. 5. The total simulation time was 1000 seconds and the sampling time was $0.02 \mathrm{~s}$.

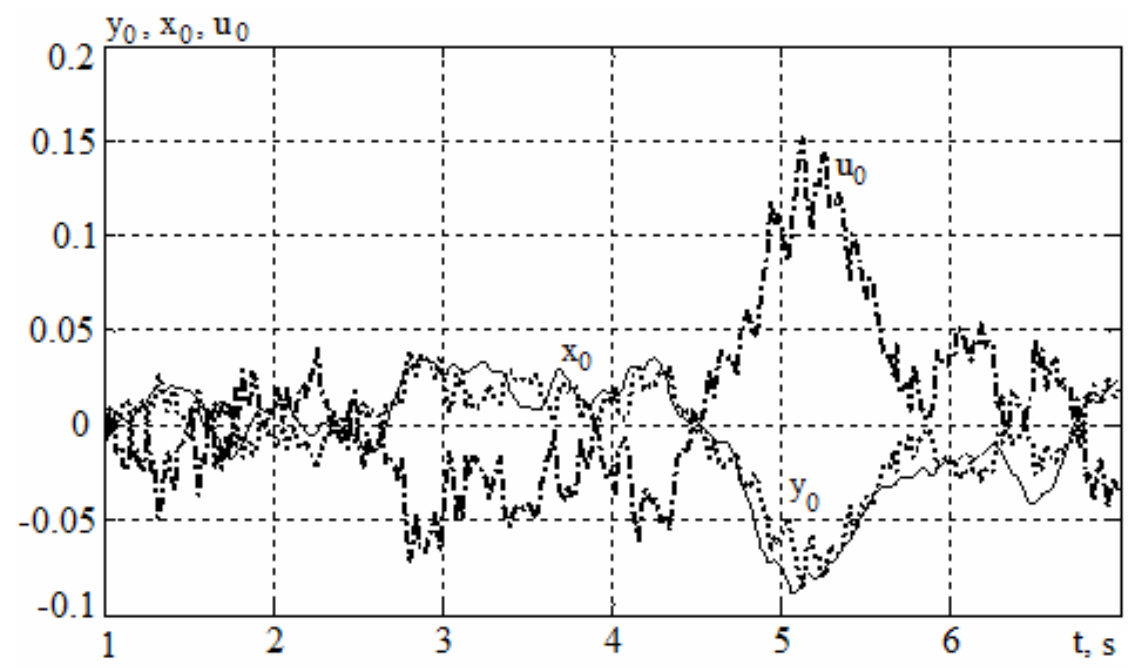

Fig. 5 - stabilization system model signals records

Statistical processing of signals (Fig. 5) by the Blackman-Tukey method [10] and approximation of the obtained estimates curves (Fig. 6) on the class of fractional-rational functions of the complex argument made it possible to find the following spectral and cross spectral densities of the signals from equations (7), (8), (16) 


$$
\begin{gathered}
S_{x 0 x 0}^{\prime}=\frac{7.3339\left|s^{2}+11.6 s+43.15\right|^{2}}{|(s+12.98)(s+10)(s+7.019)(s+2.5)|^{2}}, \\
S_{x 0 y 0}^{\prime}=\frac{0.45837(s+7.485)\left(s^{2}-13.11 s+55.92\right)\left(s^{2}+6.627 s+64.38\right)}{|(s+12.98)(s+10)(s+7.019)(s+2.5)|^{2}}, \\
S_{u 0 y 0}^{\prime}=\frac{-0.052 \mid(s+7.543)\left(s^{2}+10.88 s+\left.87.68\right|^{2}\right.}{|(s+12.98)(s+10)(s+7.019)(s+2.5)|^{2}}, \\
S_{u 0 u 0}^{\prime}=\frac{0.0286 \mid(s+7.543)\left(s^{2}+10.88 s+\left.87.68\right|^{2}\right.}{|(s+12.98)(s+10)(s+7.019)(s+2.5)|^{2}} .
\end{gathered}
$$

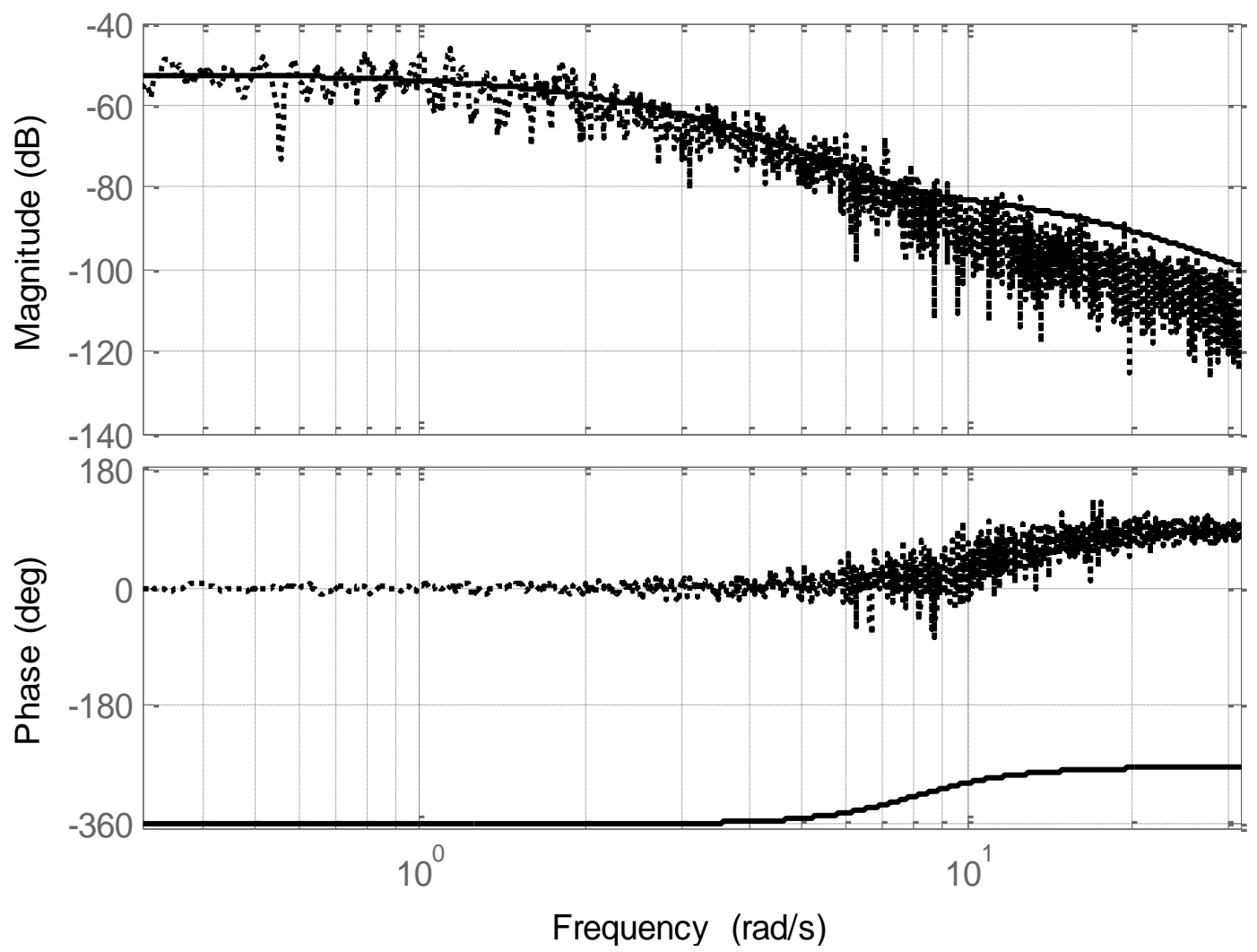

Fig. 6 - the cross spectral density $S_{\text {y0x } 0}^{\prime}$ estimate and it's approximating result

Solid line in the Fig. 6 demonstrates the approximating result. Substitution of data from expressions (20), (21) into the equation (8) and factorization of the resulting expression made it possible to find the cross spectral density $S_{\Delta \times 0}^{\prime}$ in the form

$$
S_{\Delta x 0}^{\prime}=\frac{11.184}{(s+12.98)(s+7.019)(s+2.5)} .
$$

Since the system (Fig. 1) has one input then the matrix R, which is necessary to coordinate the influence of the each vector $\mathrm{x} 0$ component on the identification quality indicator, can be accepted as one, so

$$
\Gamma=1 .
$$


Factorizing the matrix (15) relatively an imaginary axis made it possible to calculate the factor $\mathrm{D}$ in the form

$$
D=\left[\begin{array}{cc}
\frac{0.16926}{s+10} & 0 \\
0 & 0.56419
\end{array}\right]
$$

Substituting the results (25), (26) to the equation (14) proves that it is necessary to separate the following fractional-rational function

$$
T_{0}+T_{+}+T_{-}=\left[\begin{array}{ll}
\frac{-2.7081(s+5)}{(s+12.98)(s+10)(s+7.019)} & \frac{19.824}{(s+12.98)(s+7.019)(s+2.5)}
\end{array}\right] .
$$

Since the function (27) has got only stable poles then a separation result coincides with this function, so substituting the data (25)-(27) to the equation (12) determines the block matrix $\Phi$ as

$$
\Phi=\left[\frac{-16(s+5)}{(s+12.98)(s+7.019)} \frac{35.136}{(s+12.98)(s+7.019)(s+2.5)}\right] .
$$

The identification procedure is completed with determining the controller transfer function $W$, the plant polynomials $M, P$ and the fractional-rational function $\Psi$. The spectral and cross spectral densities (22), (23) substitution to the equation (16) has proved that the identified controller transfer function differs from proper transfer function on a value which is equal $8.8818 \cdot 10^{-16}$.

The plant polynomials (17), (19) identification results are as follows

$$
P=s^{2}+4 s+11.11 ; M=8.889(s+5) .
$$

The identified with the help of equation (18) fractional rational function $\Psi$ is equal to

$$
\Psi=\frac{35.136}{s+2.5} \text {. }
$$

Comparison the identification results (29), (30) with the proper data prove this results correctness.

\section{Analysis of the results}

The presence of a feedback in the stabilization system (Fig.1), which operates under the conditions of stationary random perturbations and noise interference, necessitates a significant change in the known from the monograph [1] equation (8) of the coupling between the spectral densities matrixes of perturbations and output signals.

A prerequisite for the plant and perturbations dynamics passive identification is the availability of information about the system's sensors properties.

The application of the Wiener-Kolmogorov method allows to obtain an optimal estimation of both the structure and parameters of the model dynamics of a complex multidimensional control object and perturbations by incomplete measurements of signal vectors with the help of non-ideal sensors.

The application of the Wiener-Kolmogorov method makes it possible to obtain optimal estimating both a structure and parameters of the dynamics model of the complex multidimensional control object and perturbations by incomplete measurements of signal vectors with the help of non-ideal sensors.

\section{Conclusions}

The studies carried out allow us to state that under conditions when the control system belongs to the class of stabilization systems, the signals in the control loop belong to a set of centered stationary random processes, and the noise of the sensors has different sources of origin with disturbances in the system, it is possible to unambiguously determine the matrix of transfer functions of the controller and fractional rational functions of the perturbation driver, and also to find a system of ordinary differential equations of minimal order, characterizing the dynamics of the control object.

To regularize the obtained dynamics models, it is advisable to use the identified system of differential equations of the object and the records of the corresponding components of the signal vectors.

\section{References}

[1] V.N. Azarskov et al., Metodologia konstruirovania optimalnykh system stokhasticheskoi stabilizatsii: monografia. Kiev: Knyzhnoe izdatelstvo NAU, 440 p., 2006.

[2] L.N. Blokhyn et al., Tekhnolohyy konstruyrovanyia sovremennykh konkurentosposobnykh kompleksov upravlenyia stokhastycheskym dvyzhenyem obiektov: monohrafyia. Kyrovograd: Lysenko V.F. 284 p., 2015.

[3] Metody klassicheskoi i sovremennoi teorii avtomaticheskoho upravlenia, 2nd ed., vol. 2 (Statisticheskaia dinamika $i$ identifikatsia sistem avtomaticheskoho upravlenia) K.A. Pupkov and N.D. Ehupov, Eds. MGTU, Moskow, Russia, 640 p., 2004. 
[4] V.A. Khobin and M.V. Levinskyi, Adaptyvne keruvannia obiektamy tekhnolohichnoho typu: alhorytmy pasyvnoho samonalahodzhennia koefitsiienta peredachi rehuliatoriv. Monohrafiia. Kherson: Vydavnychyi dim Helvetyka, 228 p., 2019.

[5] S.I. Osadchyi, "Tekhnolohii i alhorytm strukturnoi identyfikatsii matematychnoi modeli bahatovymirnoho rukhomoho obiekta z dovilnoiu dynamikoiu u skladi zamknenoi systemy upravlinnia," Zbirnyk naukovykh prats Kharkivskoho universytetu Povitrianykh Syl, no. 4(22), pp. 98-101, 2009.

[6] F.R. Hantmakher, Teoryia matryts, 4th ed. Moskow: Nauka, 552 p., 1988.

[7] H. Korn, Spravochnik po matematike (dlia nauchnykh rabotnikov i inzhenerov) (Transl.: Y.H. Abramovych et al., Eds) Moskow: Nauka, 831 p., 1977.

[8] F.A. Alyev et al., Vremennye y chastotnye metody synteza optymalnykh rehuliatorov. Baku: Institut fiziki AN Azerbaidzhanskoi SSR, 46 p., 1988.

[9] M. Davis, "Factoring the spectral matrix," in IEEE Transactions on Automatic Control, vol. 8, no. 4, pp. 296-305, October 1963, doi: https://doi.org/10.1109/TAC.1963.1105614.

[10] R.Otes and L. Enokson, Prikladoi analiz vremennykh riadov. Osnovnye metody (monohrafiia). Moskow: Mir, 428 p., 1982.

[11] Metody klassicheskoi i sovremennoi teorii avtomaticheskoho upravlenia, 2nd ed., vol. 3 (Syntez rehuliatorov system upravlenyia) K.A. Pupkov and N.D. Ehupov, Eds. MGTU, Moskow, Russia, 616 p., 2004.

\title{
RESEARCH OF THE SYNCHRONOUS WAVEN COORDINATION MODEL OF PRODUCTION PROCESSES
}

\author{
Dubovoi V. M. ${ }^{1}$, Yukhymchuk M. S. ${ }^{2}$ \\ ${ }^{1,2}$ Vinnytsia National Technical University, 95, Khmelnytske shosse, Vinnytsia, 21021, Ukraine \\ ORCID: ${ }^{1}$ http://orcid.org/0000-0003-0440-3643, ${ }^{2}$ http://orcid.org/0000-0002-8131-9739 \\ E-mail: ${ }^{1}$ v.m.dubovoy@gmail.com, ${ }^{2}$ umcmasha@gmail.com
}

Copyright (C) 2018 by author and the journal "Automation of technological and business - processes.

This work is licensed under the Creative Commons Attribution International License (CC BY).

http://creativecommons.org/licanses/by/4.0

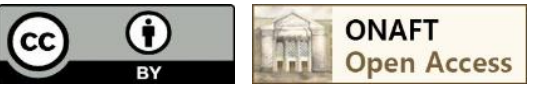

\section{DOI: https://doi.org/10.15673/atbp.v12i1.1702}

Abstract. In the article the model of one-level coordination of production processes is created and indicators of wave synchronous coordination algorithm are investigated. It is shown that in case of high complexity and fast reaction of elements to random perturbations, the case is possible when the required period of initiation of the coordination wave becomes less than the wave propagation through the system, i.e. the coordination time.

Анотація. У статті створено модель однорівневої координації виробничих процесів та досліджено показники алгоритму синхронної координації хвиль. Показано, щуо у випадку високої складності та швидкої реакції елементів на випадкові збурення можливий випадок, коли необхідний період ініціаџії координаційної хвилі стає меншим за поширення хвилі через систему, тобто час координації.

Keywords: synchronous waven algorithm, production processes, one-level coordination

Ключові слова: алгоритм синхронної хвилі, виробничі процеси, однорівнева координація

\section{Introduction}

The complications and rapid development of distributed control systems (DCS) have especially accelerated with the cheapening and micro-miniaturization of microcontrollers. It became possible to include microcontrollers in the field-level sensors and actuators. On the other hand, communication systems are developing at a rapid pace. From these two fundamental advances, the Internet of Things (IoT) was born, which in turn has pushed new research into the well-known problem of production processes coordination. After all, a large number of local "microsystems" of control requires their coordination 